\title{
合肥盆地南缘碎屑锆石定年及其对大别造山带 超高压岩石折返的指示
}

\author{
王勇生 ${ }^{*}$, 白桥，田自强，杜辉 \\ 合肥工业大学资源与环境工程学院, 合肥 230009 \\ * 通讯作者, E-mail: yshw9007@hfut.edu.cn
}

收稿日期：2019-08-21; 收修改稿日期：2019-12-17; 接受日期：2019-12-18; 网络版发表日期：2020-02-24

国家自然科学基金项目(批准号: 41572186、41872216)资助

\begin{abstract}
摘要合肥盆地形成于大别造山带同造山折返阶段, 其演化过程与造山带隆升密切相关. 在详细野外考察基础上, 本次工作对合肥盆地南缘下侏罗统防虎山组、中侏罗统三尖铺组及造山带南部的宿松杂岩内的云母石英片岩和 黑云母花岗片麻岩开展了锆石LA-ICP-MS U-Pb定年. 定年结果显示, 防虎山组砾岩及其中砾石的碎屑锆石年龄 主要集中于2.0 1.8 Ga, 与宿松杂岩岩石基本一致, 并且长石砂岩碎屑锆石年龄中缺失佛子岭群特征的 1000 900 Ma年龄峰, 表明防虎山组物源更可能为高压-超高压变质岩、古生代岩浆岩以及宿松杂岩构成的混合 物源. 三尖铺组以印支期和新元古代年龄为主，两个样品的年龄结果集中出现在 797 和 $791 \mathrm{Ma}$ (新元古代中期)和 $226 \mathrm{Ma}$ (三叠纪), 同样缺失佛子岭群碎屑锆石年龄特征。佛子岭群被掩盖的现象存在两种可能的形成机制, 一种 是大别造山带发生了部分岩石的向北折返，导致部分佛子岭群被宿松杂岩覆盖，其余部分则形成合肥盆地基底; 另一种则是俯冲过程中部分宿松杂岩岩石卷入构造加积楔, 堆积在佛子岭群之上.
\end{abstract}

关键词大别造山带, 超高压岩石折返, 合肥盆地, 下-中侏罗统, 锆石定年

\section{1 引言}

大别造山带位于秦岭-桐柏-红安-大别造山带的东 端，与红安造山带、苏鲁造山带一起构成了世界上超 高压岩石出露面积最大的地区．这些超高压变质岩为 华南板块地壳岩石俯冲至地幔深度, 经历了超高压变 质之后再折返至地表而形成的(Okay和Şengör, 1992; Yin和Nie，1993; Hacker等，1998; Li等，2000; Zheng 等, 2006). 到目前为止, 虽然多种折返模式被先后提出 (Okay和SSengör, 1992; Hacker等, 2000; 王清晨和林伟,
2002; Wang等, 2003; Zheng等, 2003; Faure等, 2003; 李 曙光等, 2005), 但超高压岩石如何由地幔深处折返至 地壳浅部仍存在较大争议.

超高压岩石的折返过程直接决定了其地壳浅部的 分布状态, 因而其在地壳浅部的分布是衡量超高压岩 石折返模式正确与否的重要依据. 但大别造山带在后 碰撞阶段发生了强烈的伸展和隆升活动(Wang等, 1998; Ratschbacher等, 2000; 李秋立等, 2013; 王勇生 等, 2014, 2018; Lin等, 2015; Ji等, 2017), 导致造山带内 大面积超高压岩石被剥蚀，位于超高压变质岩下部的 
混合岩直接出露地表．现今超高压变质岩主要出露于 造山带中东部，其他位置仅在北大别单元边缘零星出 露(Liu Y C等, 2005; Lin等, 2007). 而且, 受后碰撞阶 段隆升的影响，高压-超高压岩石总体倾向SE，与折返 过程中倾向NW的逆冲岩片的分布状态明显不同．这 直接导致无法恢复超高压岩石在同碰撞折返结束后的 展布状态，从而为构建和检验合适的折返模式造成了 困难. 现有的折返模式均认为造山带岩石主体向SE方 向折返，但超高压岩石是否存在向北的折返？如果存 在，那么向北的折返物质中包含哪些岩石类型? 向北 折返的距离究竟有多远? 对周边地区产生何种影响? 这些问题的回答有助于更好地认识大别造山带的折返 过程, 但要求首先查明深俯冲岩石折返至地壳浅部之 后的展布状态.

大别造山带北部毗邻的合肥盆地形成演化过程与 造山带呈密切的耦合关系(赵宗举等, 2000; Liu等, 2003, 2010; Li等, 2005; Meng等, 2007; Zhu等, 2017). 地层中古水流方向、碎屑锆石年龄、超高压矿物包裹 体的发现等均指示大别造山带为其物源区，因而合肥 盆地是分析大别造山带隆升演化历史的极佳研究对 象. 除上侏罗统地层缺失外, 合肥盆地南缘连续出露侏 罗系和白严系地层. 尤其是早-中侏罗世时，合肥盆地 为大别造山带的后陆盆地, 造山带出露至地表的岩石 被剥蚀并搬运至合肥盆地内沉积形成下-中侏罗统地 层，为分析同造山折返阶段出露至地表的岩石分布状 态奠定了重要的基础.

基于以上分析, 在详细的野外观察基础上, 本次工 作在合肥盆地南缘下侏罗统防虎山组、中侏罗统三尖 铺组以及 2 个宿松杂岩样品开展锆石激光-电感耦合等 离子质谱仪(LA-ICP-MS) U-Pb年龄测定, 为大别造山 带同造山折返结束时构造-岩石单元的分布提供证据, 同时也可以为华南板块北缘岩石组成提供信息.

\section{2 区域地质背景}

大别造山带位于中国中东部，其南侧为扬子前陆 褶皱冲断带, 北侧为合肥盆地, 东侧为下扬子地区，西 侧为红安造山带. 其中造山带向东终止于㸚庐断裂带, 向西则以商城-麻城断裂为界(图1). 目前大别造山带普 遍被划分为五个岩石-构造单元，自北向南依次为北淮 阳单元、北大别单元、南大别高压-超高压榴辉岩单
元、宿松杂岩带和张八岭群(徐树桐等，1992; Zhai等， 1995; Zheng等, 2005).

多年来的研究表明，大别造山带主要形成于印支 期华南、华北板块的陆-陆碰撞过程中(Mattauer等, 1985; Okay和Şengör, 1992; Yin和Nie, 1993; 张国伟等, 1996; Hacker等, 1998). 北淮阳单元主要包括佛子岭群 和卢镇关群，其中佛子岭群为形成于古生代的复理石 沉积(徐树桐等, 1992; Zheng等, 2005; Zhu等, 2017), 卢镇关群则形成于新元古代岩浆活动中 (Zheng等, 2004; 吴元保等, 2004; 刘景波等, 2013), 两者均经历了 较低级变质作用. 北大别单元为造山带后碰撞伸展阶 段的核心位置(Ratschbacher等, 2000; 杨坤光等, 1999; 王勇生等, 2014), 主要包括早白严世混合岩及岩浆岩 (Wu等, 2007; Wang等, 2007; 赵子福和郑永飞, 2009; $\mathrm{He}$ 等, 2011; Chen等, 2015; 王勇生等, 2018), 边缘位置 保存有残存的榴辉岩(Liu Y C等, 2005; Lin等, 2007). 超高压-高压榴辉岩单元位于北大别单元南东侧, 岩石 产状总体倾向 SE，表现为叠置于北大别单元之上的折 返岩片(Faure等，2003；Wang等，2007，2011；Lin等， 2009). 大量的年代学成果表明，华南板块地壳岩石在 235Ma左右发生超高压变质作用(Li等，2000；Liu等， 2006; Wawrzenitz等, 2006; Zheng等, 2006), 随后超高 压岩石以上盘向NW的运动形式向SE方向折返(Hacker等, 2000; Faure等, 2003; Lin等, 2009), 在经历了多期 折返过程之后出露地表. 位于大别造山带南部的张八 岭群和宿松杂岩带分别为经历了高压绿片岩相和高压 角闪岩相的新元古代沉积地层和火山岩(魏春景等, 2000; 赵田等, 2014), 因而也被称为高压绿片岩相-角 闪岩相单元. 250 220 Ma的 ${ }^{40} \mathrm{Ar}^{39} \mathrm{Ar}$ 年龄指示其也经 历了印支期变质作用(Hacker和Wang, 1995; 江来利等, 2003; 杨坤光等, 2011).

大别造山带三面被盆地围绕，其中东侧的潜山盆 地晚中生代为受控于郯庐断裂带伸展活动的裂陷盆地 (Grimmer等, 2003; Zhu等, 2005), 南北两侧分别为位于 造山带前陆位置的黄石盆地(Yang等, 2010; Liu S F等, 2005)和后陆的合肥盆地( Liu等，2003； Li等，2005; Meng等, 2007; Zhu等, 2017). 合肥盆地位于华北克拉 通东南缘, 其北侧为淮南-蚌埠隆起, 两者之间以寿县定远断裂相连; 东侧为隶属于华南板块的张八岭隆起, 并以郯庐断裂带相接(朱光等, 2011). 三叠纪末-早侏罗 世初，大别造山带内岩石向北的逆冲作用在造山带北 


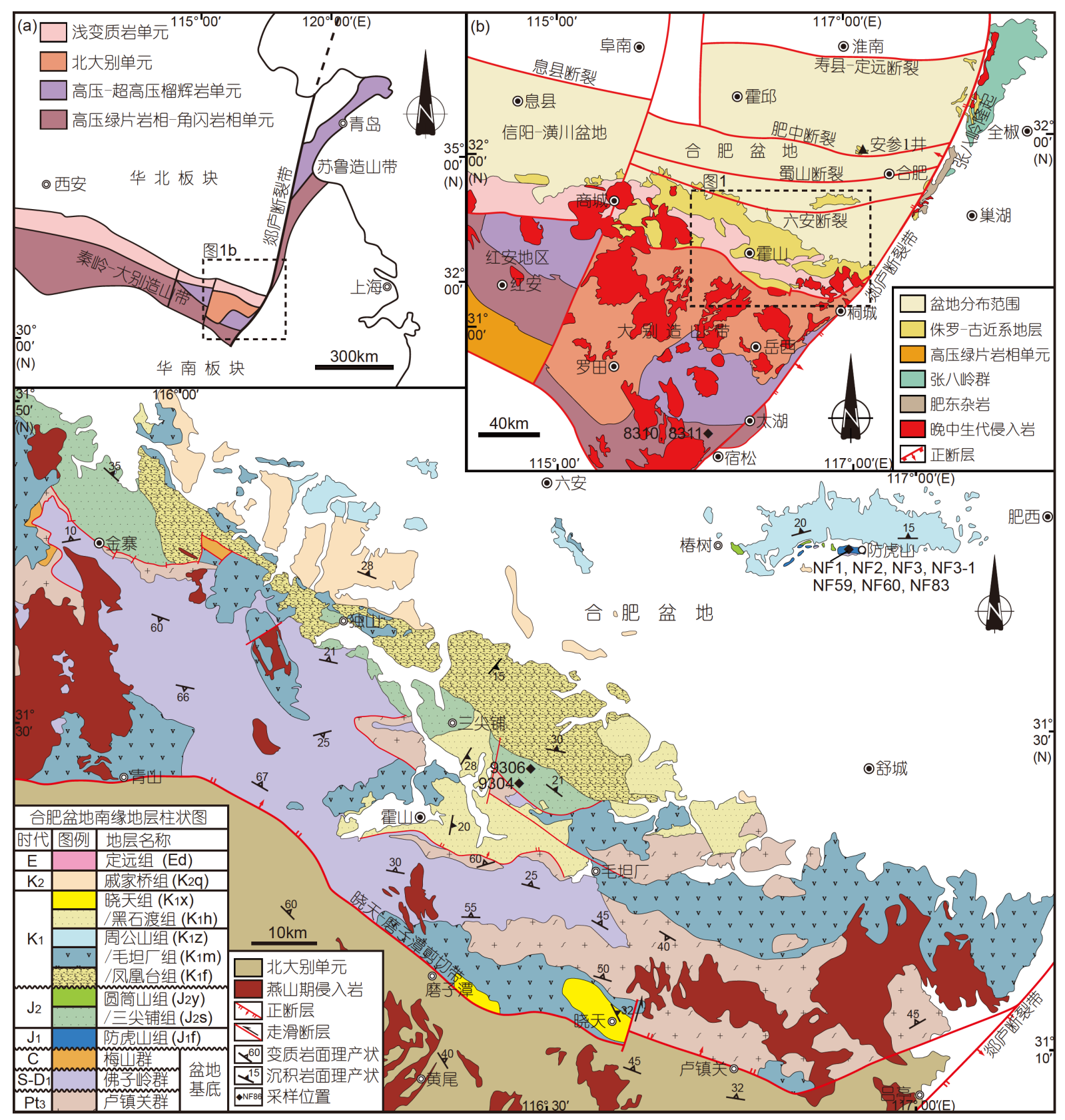

图 1 合肥盆地南缘及周边地区地质简图

(a) 秦岭-桐柏-红安-大别索引图; (b) 大别造山带及合肥盆地构造框架简图

侧形成挤压挠曲盆地(Liu等, 2003). 合肥盆地早侏罗世 开始接受沉积，发育下侏罗统防虎山组、中侏罗统圆 筒山组/三尖铺组(Liu等，2003；Li等，2005；Meng等， 2007); 晚侏罗世中国东部普遍隆升，盆地缺失上侏罗 统沉积(朱光等, 2018). 早白严世初, 在区域伸展背景 下合肥盆地转变为裂陷盆地, 并一直持续至古近纪
(Liu等, 2003; 孟庆任等, 2005; Meng等, 2007; 朱光等, 2011), 导致部分沉积地层掩盖了造山带北缘部分岩石 (石永红等, 2014; Zhu等, 2017). 新近纪以来的区域挤 压结束了合肥盆地的沉积历史(刘国生等, 2006). 多年 来的研究表明, 合肥盆地内地层的物源主要来自于大 别造山带(Liu等，2003； Li等，2005; Wan等，2005; 
Meng等, 2007; Zhu等, 2017). 而下侏罗统防虎山组碎 屑锆石中高压矿物包裹体的发现及大量印支期碎屑锆 石年龄的获得表明深俯冲的造山带岩石在早侏罗世已 出露地表( Li等, 2005).

\section{3 地层特征与样品描述}

合肥盆地南缘侏罗-白严系厚度可达5000 7000m, 沿造山带北缘霍山-金寨地区呈带状出露, 主要为一套 陆相碎屑沉积夹火山岩-火山碎屑岩, 其中下白严统地 层最为发育(李任伟等, 2005; Meng等, 2007). 合肥盆 地南缘自下而上主要发育下侏罗统防虎山组、中侏 罗统三尖铺组/圆筒山组、下白严统风凰台组/周公山 组/毛坦厂组、黑石渡组/晓天组及上白严统戚家桥组 (图1).

下侏罗统防虎山组是合肥盆地中的最老地层，仅 出露于肥西县防虎山一带(图1). 露头上防虎山组主要 由厚层砾岩、含砾粗砂岩和长石砂岩组成，夹少量薄 层细砂岩和粉砂岩(图2), 不整合覆盖在北淮阳单元浅 变质岩之上(Li等, 2005; 石永红等, 2014). 防虎山组中 多硅白云母的存在、大量印支期及新元古代碎屑锆石 年龄的获得以及碎屑锆石中柯石英包裹体的发现 $(\mathrm{Li}$ 等, 2005), 均明显地表明地层物源为大别造山带. 位于 肥中断裂以北的安参 1 井岩芯揭示下侏罗统地层表现 为厚层砂质泥岩夹薄层泥质粉砂岩(徐佑德等，2002), 表现为浅湖-半深湖相沉积. 下侏罗统地层由南向北沉 积地层粒度变细的特征也表明合肥盆地下侏罗统的沉 积物源为南侧的大别造山带.

防虎山组底部主要表现为灰白色含砾粗砂岩夹长 石砂岩, 砾岩中砾石主要为片麻岩、石英岩, 部分砾石 为糜棱岩(图2a). 砾石大小不一, 较大者可达几十厘米, 小者约 $1 \mathrm{~cm}$, 多数砾石介于 $2 \sim 10 \mathrm{~cm}$ (图 $2 \mathrm{a} \sim 2 \mathrm{c}$ ). 显微镜 下观察显示，糜棱岩砾石中石英、长石均表现为完全 的动态重结晶(图3a); 具有清晰片麻理的片麻岩砾石 也同样表现为石英动态重结晶，岩石中矿物颗粒大小 基本一致(图3b). 石英岩砾石分为两类: 一类变形明显 较强, 石英变形特征与糜棱岩砾石一致(图3c); 另一类 岩石中石英几乎未变形，颗粒间隙充填有少量的黏土 矿物(图3d). 这些黏土矿物在正交偏光下具清晰的彩 色干涉色，指示其主要为伊利石，但并未形成颗粒相 对较大的绢云母，表明其可能仅经历了成岩阶段，并
未经历较高温度的变质作用. 如果以未变形石英岩砾 石中石英颗粒大小为基准，强变形砾石中的石英颗粒 表现为明显细粒化(图3c).

中侏罗统三尖铺组/圆筒山组表现为同期异相沉 积, 其中圆筒山组出露于肥西防虎山一带, 主要由细粒 砂岩构成. 而三尖铺组则广泛分布于合肥盆地南部边 缘(Meng等, 2007), 不整合覆盖于北淮阳单元之上, 底 部地层主要由厚层砾岩构成, 与平行层状含砾砂岩和 粗砂岩共生. 砾岩中砾石分选差, 多呈棱角状或次磨 圆状; 成熟度低, 砾石成份多为长英质片麻岩. 地层 中-上部则由交错层砂岩和平行层状砂岩构成, 局部出 现砾岩透镜体. 金寨地区三尖铺组发育完整, 由底部砾 岩向上部砂岩连续分布. 霍山地区则缺失底部砾岩, 主 要出露中-上部的厚层砂岩(图2d).

位于造山带南部的宿松杂岩广泛出露新元古代沉 积岩变质形成的云母石英片岩及一系列正片麻岩(江 来利等, 2003). 宿松以北地区以云母石英片岩为主, 夹 有少量正片麻岩. 云母石英片岩面理产状相对稳定, 总 体向SE方向陡倾, 倾角 $50^{\circ} \sim 60^{\circ}$. 岩石中局部发生小禇 皱(图2e), 但并不影响岩石的总体展布特征. 片麻岩呈 透镜体形式存在于片岩中, 体积较大者可达 $10 \mathrm{~m} \times 10 \mathrm{~m}$. 样品8310为云母石英片岩, 8311 则为分布于片岩中的 黑云母花岗片麻岩(图2f). 宿松以南则主要出露正片 麻岩, 片岩类岩石较少.

\section{4 锆石定年}

\section{1 定年方法}

为了获取岩石的物源信息，本次工作在合肥盆地 下侏罗统防虎山组、中侏罗统三尖铺组中采集砾岩和 砂岩样品以及宿松杂岩云母石英片岩和黑云母花岗片 麻岩挑选锆石进行LA-ICP-MS U-Pb年龄测定. 样品分 选工作在河北省区域地质调查研究所开展, 首先采用 常规方法粉碎样品, 并用重液和磁选方法分选出单颗 粒锆石; 然后利用双目镜手工挑选出晶形和透明度较 好的锆石颗粒粘贴在环氧树脂表面，其中沉积岩和石 英片岩样品选择 250 颗锆石, 片麻岩样品选择 200 颗. 对锆石表面抛光使其内部结构完全出露后进行透射光 和反射光照相，并据此选择晶体特征良好的锆石进行 阴极发光照相(部分图像如图4所示); 最后根据阴极发 光图像选择内部结构均匀、无包裹体的锆石颗粒开展 

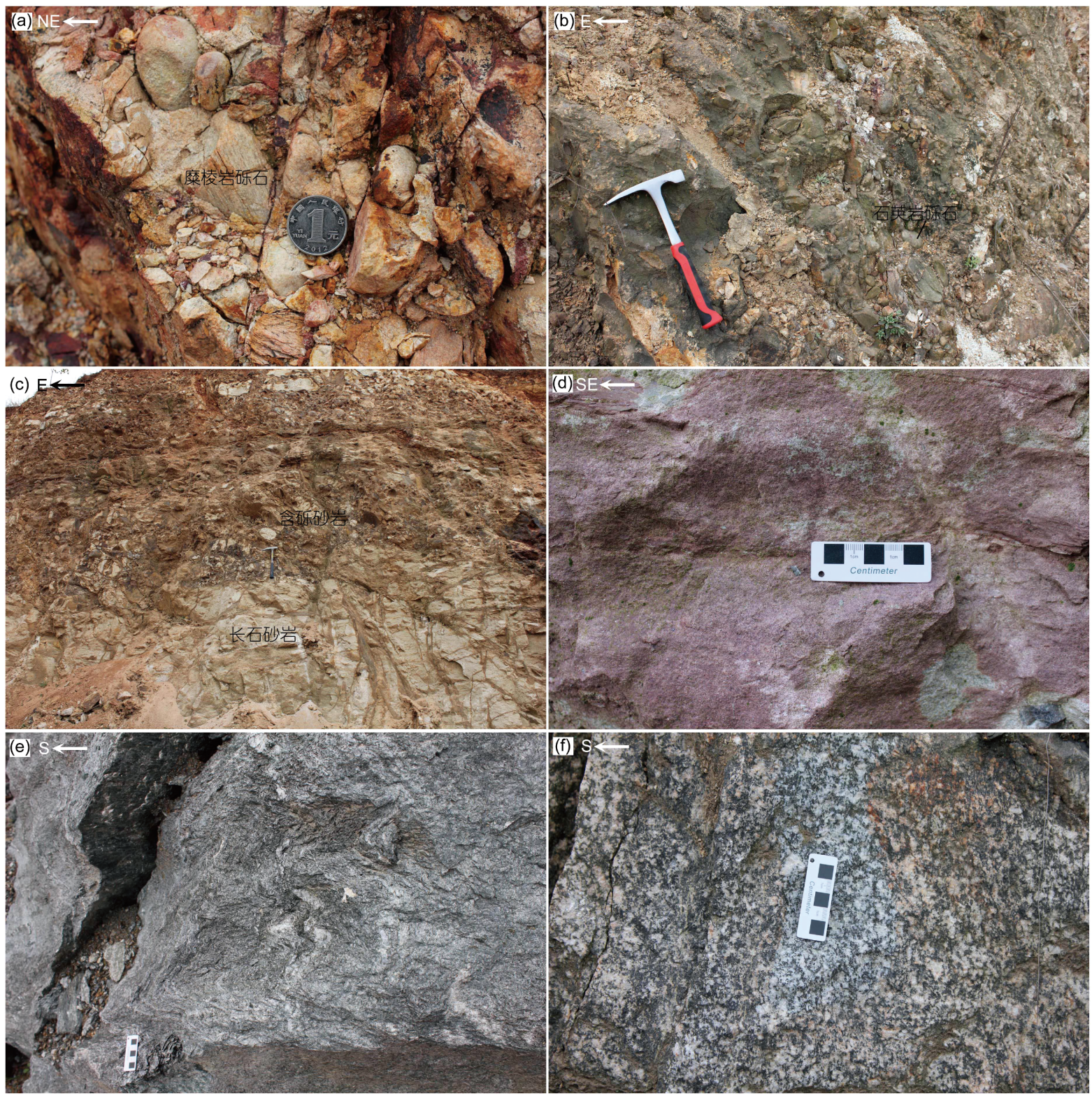

图 2 合肥盆地侏罗系地层及宿松杂岩岩石野外照片

(a) 含糜棱岩砾石的防虎山组砾岩; (b) 以石英岩砾石为主的防虎山组砾岩; (c) 防虎山组下部位于砾岩层之间的长石砂岩; (d) 中侏罗统三尖铺 组紫红色砂岩; (e) 局部发育褶皱的云母石英片岩; (f) 宿松杂岩黑云母花岗片麻岩

$\mathrm{U}-\mathrm{Pb}$ 年代学测试.

本次年代学测试工作在合肥工业大学资源与环境 工程学院质谱实验室开展, 利用LA-ICP-MS完成锆石 原位U-Pb同位素和微量元素分析, 测试仪器为GEOLAS激光剥蚀系统和Agilent 7500a质谱仪, 采用锆石 标准91500作外标进行同位素分馏校正, 详细的仪器 条件同Yan等(2015). 测试误差为 $1 \sigma$. 本次工作中选取
谐和度 $\geq 90 \%$ 的样品点进行数据分析, 其中小于 $1.0 \mathrm{Ga}$ 的锆石年龄为 ${ }^{206} \mathrm{~Pb} /{ }^{238} \mathrm{U}$ 年龄, 大于 $1.0 \mathrm{Ga}$ 的锆石年龄 为 ${ }^{207} \mathrm{~Pb} /{ }^{206} \mathrm{~Pb}$ 年龄. 数据处理软件为中国地质大学(武 汉)开发的ICPMSDataCal 8.0. 采用软件Isoplot 3.14为 沉积岩和石英片岩样品绘制年龄分布频谱图, 为片麻 岩样品绘制谐和图并计算加权平均年龄 (Ludwig, 2004). 分析结果见网络版附表1(http://earthen.scichina. 

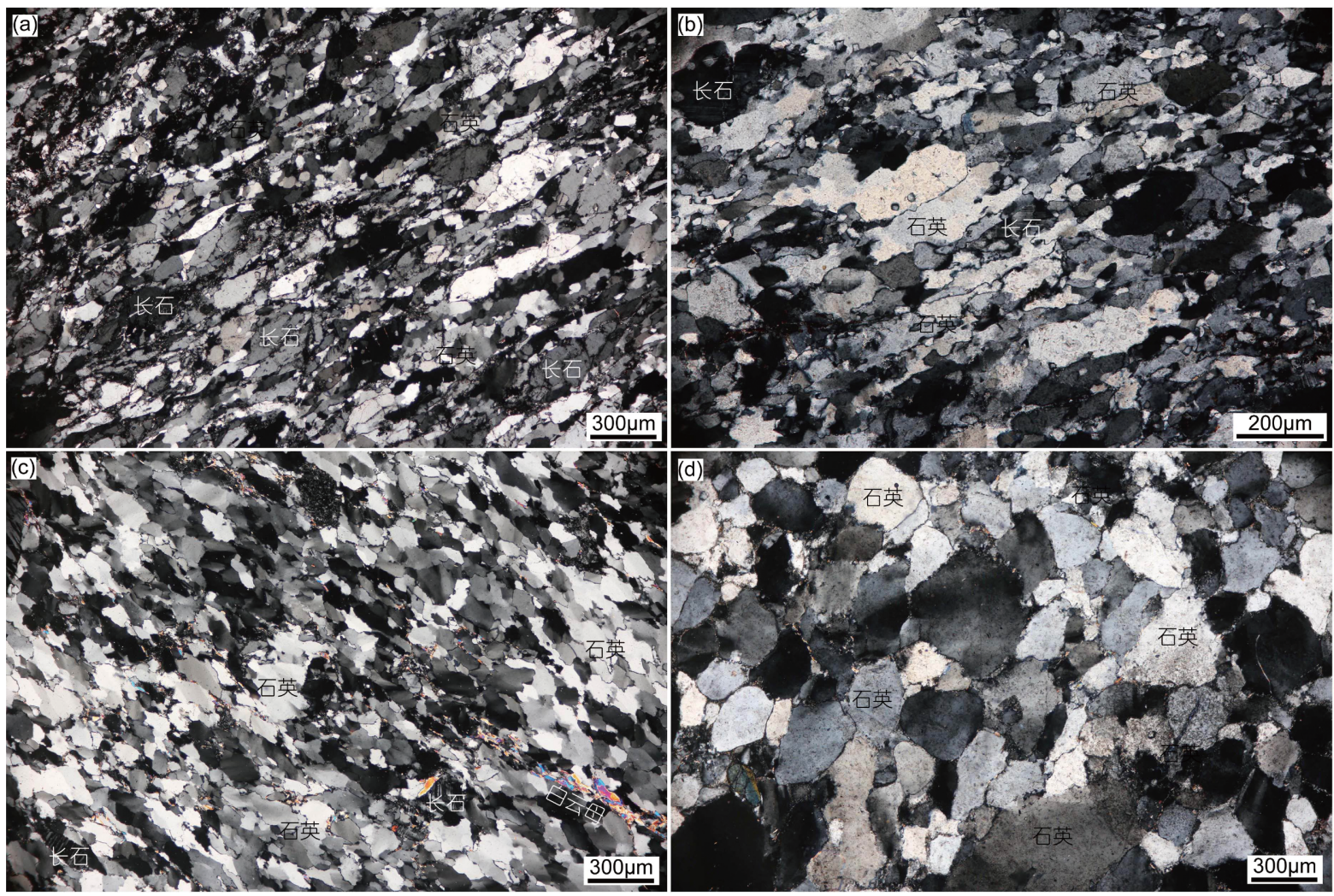

图 3 下侏罗统防虎山组砾岩中砾石显微照片

(a) 糜棱岩砾石, 长石石英均发生动态重结晶; (b) 发生塑形变形的片麻岩砾石; (c) 强变形的石英岩砾石, 石英动态重结晶; (d) 未变形的石英岩 砾石, 石英呈浑圆状

com).

\section{2 定年结果}

NF1为采自下侏罗统防虎山组出露地层的最底部 的砾岩样品, NF59为相同露头点去除所有砾石之后的 胶结物(表1); NF2采自于NF1西侧的砾岩, NF60为该露 头点岩石中的石英岩砾石; NF3采自于相对较上层位 的砾岩, NF3-1为其中的石英岩砾石; NF83为砾岩层 上部的粗粒长石砂岩. 9304、9306为中侏罗统三尖铺 组粗粒砂岩.

合肥盆地侏罗系地层中锆石粒度大小不一，长度 最小 $100 \mu \mathrm{m}$ ，最大可达 $300 \mu \mathrm{m}$ 以上; 多数锆石呈碎片 状, 形状为浑圆状或短柱状, 极少量锆石呈自形, 总体 上显示了碎屑锆石的特征(图4)。阴极发光图像显示, 形成时间早于印支期的锆石均发育振荡环带, 其 $\mathrm{Th} / \mathrm{U}$ 比除少量稍小于 0.1 外, 其余均明显大于 0.1 (附表 1 ), 表 明这些锆石为岩浆锆石(Belousova等, 2002; 吴元保和
郑永飞, 2004). 印支期锆石则主要表现为板状构造.

防虎山组砾岩(NF1、NF2、NF3)的年龄结果主要 介于 $2.0 \sim 1.8 \mathrm{Ga}$ ，主年龄峰值分别为 $1883 、 1879$ 、 $1894 \mathrm{Ma}$ (图5); 其他年龄结果明显较少, 主要分布于新 元古代及古元古代初期，最小年龄介于 660 737 Ma(附 表1), 并未出现印支期和古生代年龄结果. 相对而言, 砾岩中砾石的年龄结果更加集中，砾岩胶结物和长石 砂岩的年龄结果则更丰富. 砾石样品NF60中几乎所有 年龄结果均介于1.9 1.8Ga, 年龄峰值为 $1831 \mathrm{Ma}$; 另一 个砾石样品NF3-1主年龄峰值相对较大, 为 $1934 \mathrm{Ma}$, 此 外还存在较明显的古元古代初期的次级年龄峰，峰值 年龄为 $2478 \mathrm{Ma}$. 作为砾岩胶结物的NF59中新元古代 和古生代年龄明显增加, 主年龄峰为 $1984 、 746 \mathrm{Ma}$, 古 生代次级年龄峰值477Ma(图5). NF83为防虎山组底部 的粗粒长石砂岩，存在 $770 、 397 、 225 \mathrm{Ma}$ 三个主要年 龄峰和1991、1836Ma两个次要年龄峰(图5), 最小年 龄为 $210 \mathrm{Ma}$. 与砾岩样品相比, 长石砂岩中古元古代年 

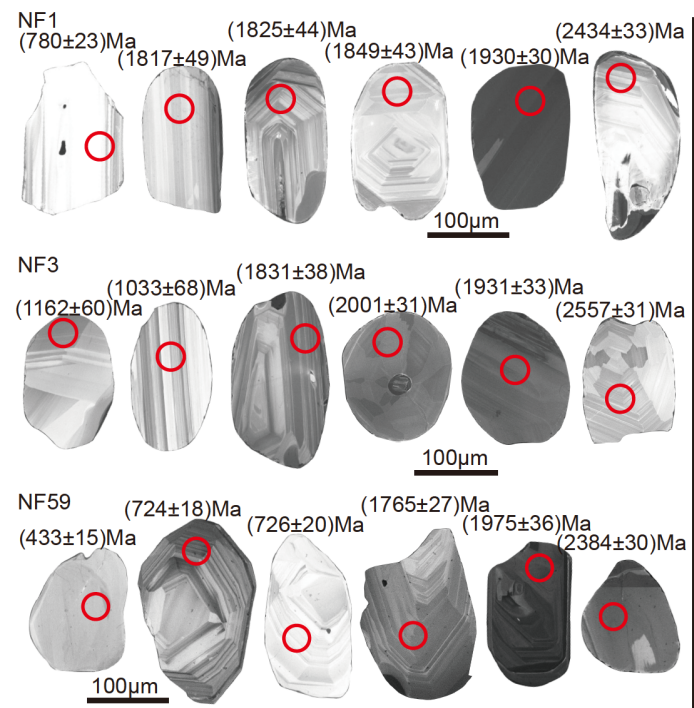

NF83
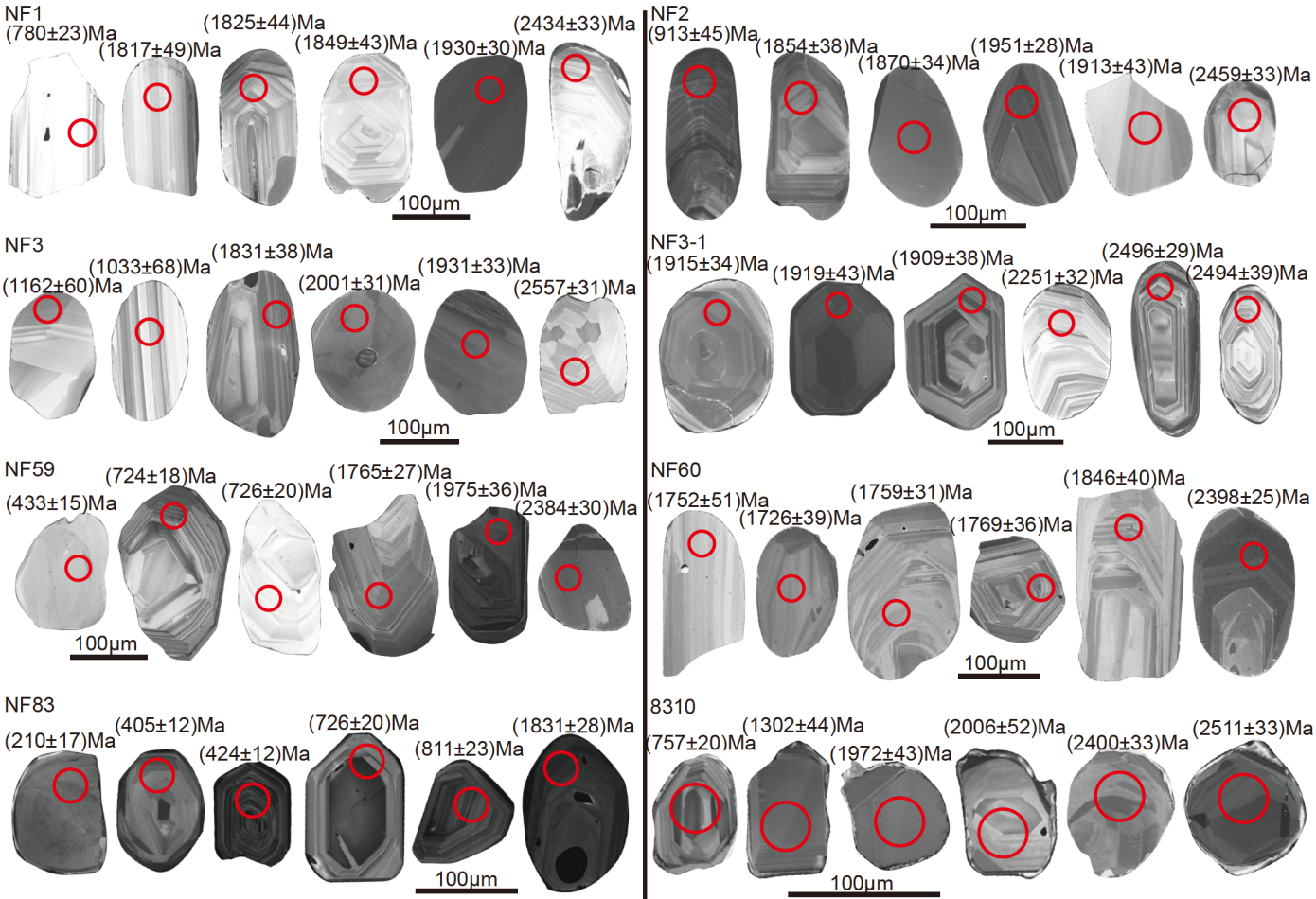

NF3-1
$(1915 \pm 34)$
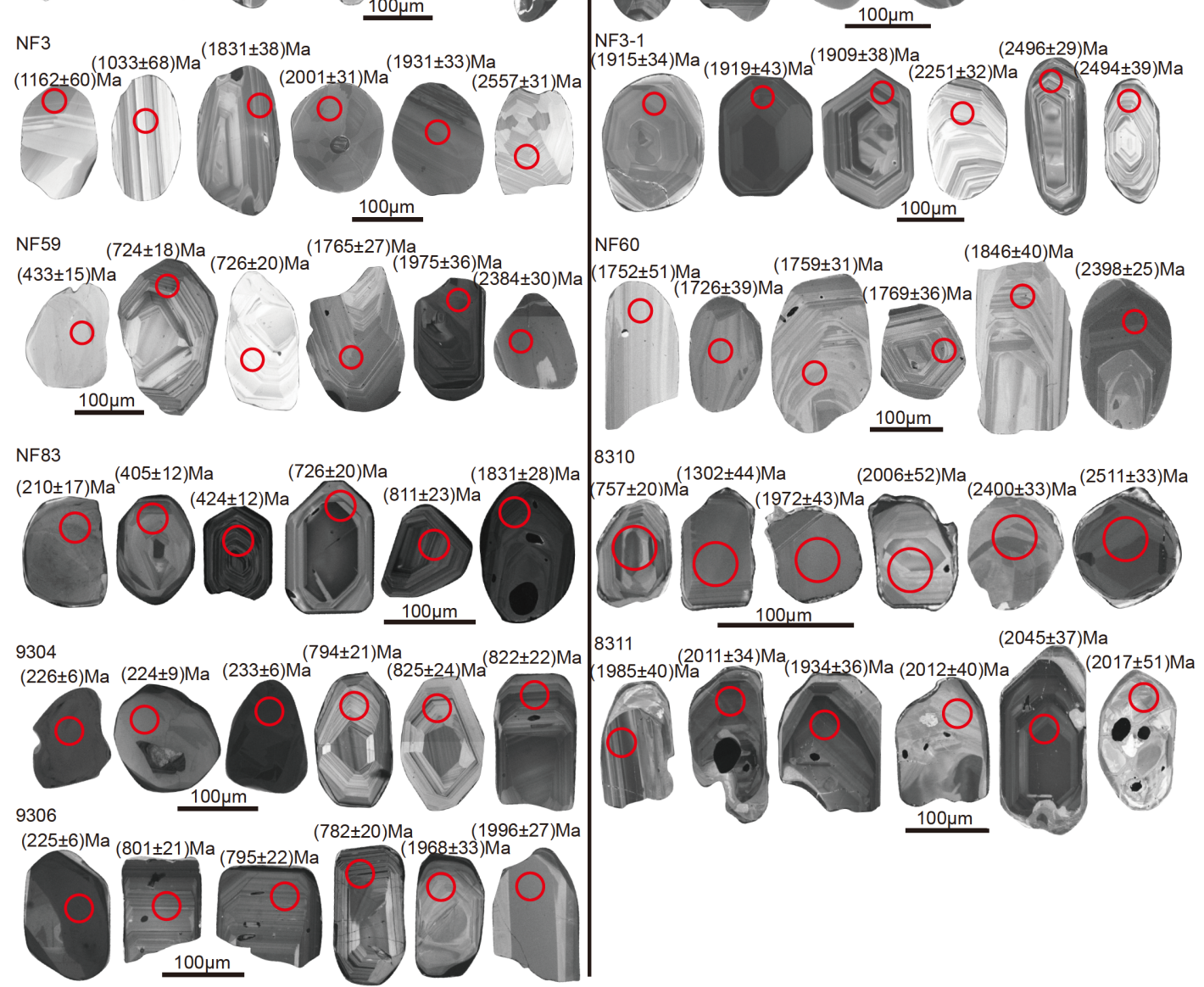

图 4 合肥盆地侏罗系地层及宿松杂岩岩石部分碎屑锆石阴极发光(CL)图像

红圈为定年测试位置

表 1 合肥盆地南缘沉积岩及宿松杂岩样品特征一览表

\begin{tabular}{|c|c|c|c|c|c|}
\hline \multirow{2}{*}{ 样品号 } & \multirow{2}{*}{ 采样位置 } & \multirow{2}{*}{ 地层 } & \multirow{2}{*}{ 测试对象 } & \multicolumn{2}{|c|}{ 锆石年龄峰值(Ma) } \\
\hline & & & & 主要峰值 & 次要峰值 \\
\hline 9304 & $31^{\circ} 27^{\prime} 27.7^{\prime \prime} \mathrm{N}, 116^{\circ} 26^{\prime} 26.1^{\prime \prime} \mathrm{E}$ & \multirow{2}{*}{$\begin{array}{c}\text { 三尖铺组 } \\
\left(\mathrm{J}_{2} \mathrm{~s}\right)\end{array}$} & 粗砂岩 & $226 、 797$ & 395 \\
\hline 9306 & $31^{\circ} 26^{\prime} 0.6^{\prime \prime} \mathrm{N}, 116^{\circ} 31^{\prime} 1.3^{\prime \prime} \mathrm{E}$ & & 粗砂岩 & 791 & 232、2011 \\
\hline NF83 & $31^{\circ} 41^{\prime} 20.7^{\prime \prime} \mathrm{N}, 116^{\circ} 53^{\prime} 8.9^{\prime \prime} \mathrm{E}$ & \multirow{5}{*}{$\begin{array}{c}\text { 防虎山组 } \\
\left(J_{1} f\right)\end{array}$} & 粗粒长石砂岩 & $225 、 397 、 770$ & 1836、1991 \\
\hline NF3 & $31^{\circ} 41^{\prime} 10.6^{\prime \prime} \mathrm{N}, 116^{\circ} 53^{\prime} 46.4^{\prime \prime} \mathrm{E}$ & & 砾岩 & 1894 & $1208 、 2467$ \\
\hline NF3-1 & & & 石英岩砾石 & 1934 & 2478 \\
\hline $\begin{array}{c}\text { NF2 } \\
\text { NF60 }\end{array}$ & $31^{\circ} 41^{\prime} 24.9^{\prime \prime} \mathrm{N}, 116^{\circ} 54^{\prime} 45.0^{\prime \prime} \mathrm{E}$ & & $\begin{array}{c}\text { 砾岩 } \\
\text { 石英岩砾石 }\end{array}$ & $\begin{array}{l}1879 \\
1831\end{array}$ & 743、989、2485 \\
\hline $\begin{array}{l}\text { NF1 } \\
\text { NF59 }\end{array}$ & $31^{\circ} 41^{\prime} 23.5^{\prime \prime} \mathrm{N}, 116^{\circ} 55^{\prime} 2.1^{\prime \prime} \mathrm{E}$ & & $\begin{array}{c}\text { 砾岩 } \\
\text { 砾岩胶结物 }\end{array}$ & $\begin{array}{c}1883 \\
\text { 746、1894 }\end{array}$ & $\begin{array}{c}752 、 2470 、 2688 \\
447\end{array}$ \\
\hline 8310 & $30^{\circ} 23^{\prime} 46.8^{\prime \prime} \mathrm{N}, 115^{\circ} 53^{\prime} 16^{\prime \prime} \mathrm{E}$ & \multirow{2}{*}{ 宿松杂岩 } & 石英云母片岩 & $834 、 2005 、 2460$ & 1336,1828 \\
\hline 8311 & $30^{\circ} 18^{\prime} 26.4^{\prime \prime} \mathrm{N}, 115^{\circ} 54^{\prime} 3.2^{\prime \prime} \mathrm{E}$ & & 黑云母花岗片麻岩 & 1987 & - \\
\hline
\end{tabular}



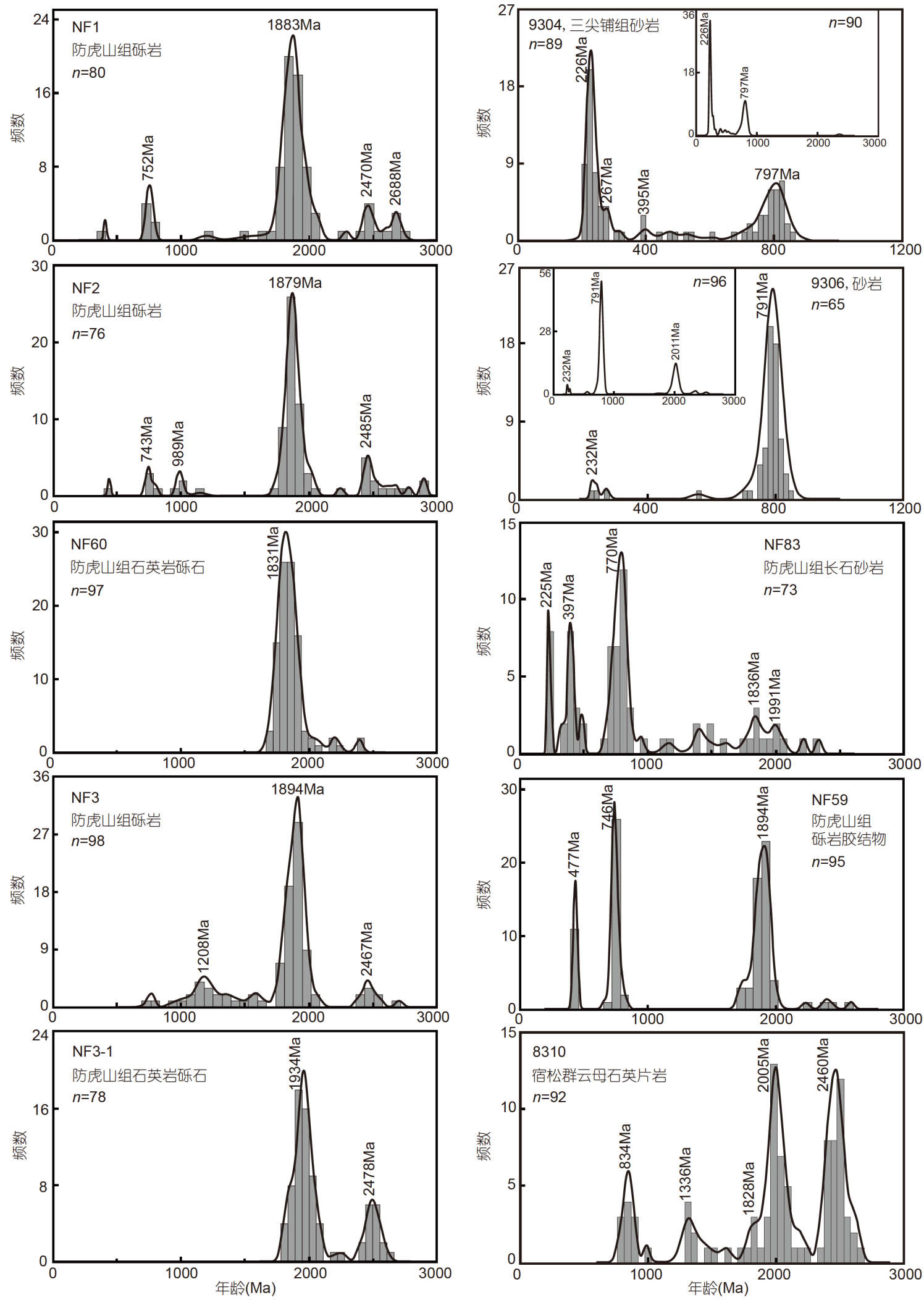

图 5 合肥盆地侏罗系沉积岩及宿松杂岩石英云母片岩年龄结果分布频谱图 
龄明显减少，而古生代早期及印支期年龄则大量出现.

三尖铺组两个砂岩样品中9304出露位置更靠近造 山带, 其年龄结果主要分布于新元古代或印支期, 年龄 峰值为797和 $226 \mathrm{Ma} ; 9306$ 则主要为新元代年龄结果, 年龄峰值为791Ma(图5). 虽然两样品隶属于同一地层, 但年龄结果却存在少许差别，其中9306具有更少的印 支期年龄结果.

宿松杂岩中云母石英片岩样品8310中存在两个主 年龄峰和三个次级年龄峰(图5). 主年龄峰值为2005、

$2460 \mathrm{Ma}$ ，次级年龄峰值分别为 $834 、 1336$ 和 $1828 \mathrm{Ma}$, 表明其沉积岩原岩形成于新元古代，地层物质主要来 源于太古代末-古元古代. 样品8311为黑云母花岗片麻 岩, 其加权平均年龄为1987Ma(图6).

\section{5 大别造山带北缘构造-岩石单元展布特征}

碎屑锆石定年是获取地层物源信息的重要手段 (Andersen, 2005). 通常来说, 砾岩并不适合用来开展沉 积物源分析, 其中最主要的原因就是砾岩多为快速堆 积的洪积物，其物源为单一的相邻高地貌区域. 但本 次工作的目的就是为了分析其南侧相邻位置的物质组 成，而造山带内其他构造-岩石单元的物源信息则需要 被屏蔽. 在这种情况下, 砾岩的形成过程有力地保证了 其他位置的物源没有混入，因而成为了最合适的研究 对象.

\section{1 下侏罗统防虎山组物源分析}

防虎山组地表主要出露砾岩及粗粒长石砂岩, 表

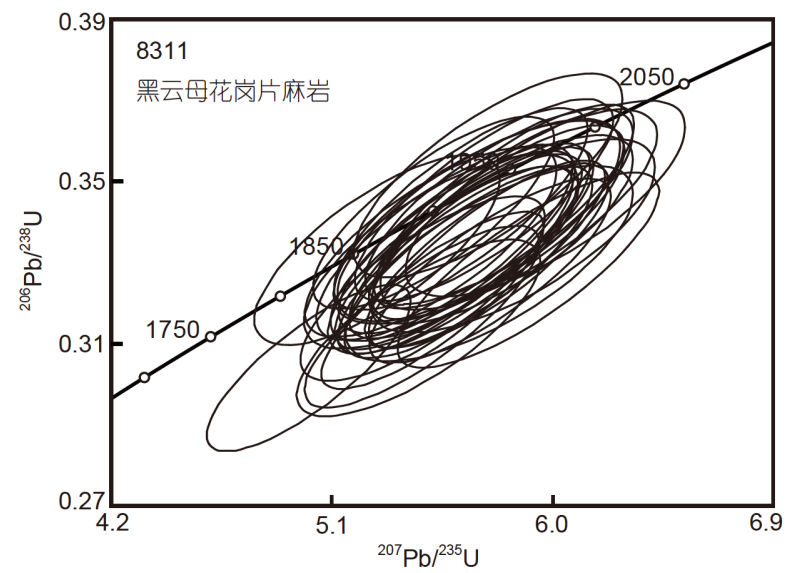

现为近源沉积, 指示其部分物源应位于其旁侧相邻的 位置. 值得注意的是, 目前造山带内高压-超高压变质 岩与防虎山组砾岩出露位置相距较远. 即使考虑到折 返结束时北大别单元顶部覆盖有高压-超高压变质岩, 以其北界的晓天-磨子潭断裂计算，其距离也超过 $100 \mathrm{~km}$. 因而，如果防虎山组中高压-超高压变质岩物 质来自于北大别单元顶部，则应明显表现为长距离搬 运, 具有高成熟度. 这与现今防虎山组出露低成熟度 的砾岩和长石砂岩相矛盾. 因此, 是否防虎山组南侧 邻近位置在早侏罗世时分布有高压-超高压变质岩? 如果不是, 究竟哪种物质分布在其旁侧?

现有的研究表明, 大别造山带内岩石在折返至地 表浅部时表现为多个岩片垂向叠置(Faure等，2003; Wang等, 2007, 2011; Lin等, 2009), 其中由上而下依次 为宿松杂岩和张八岭群、高压变质岩、超高压变质岩 和北大别单元. 因而, 在造山带隆升剥蚀过程中, 首先 接受剥蚀的岩石单元应为宿松杂岩和张八岭群, 然后 才是高压-超高压变质岩. 作为合肥盆地内最老地层, 下侏罗统防虎山组应当接受造山带最顶部岩石的剥蚀 沉积.

本次工作显示, 防虎山组三个砾岩样品及两个石 英岩砾石的主要年龄峰值均介于 $2.0 \sim 1.8 \mathrm{Ga}$ (图5), 表明 地层中砾石的物源物质主要形成于该时期. 纵观整个 造山带, 含有大量2.0 1.8Ga物质的构造-岩石单元仅 有宿松杂岩. 由于宿松杂岩云母片岩中含有大量新元 古代年龄信息(图7), 因而需要确定是否存在仅出现 $2.0 \sim 1.8 \mathrm{Ga}$ 年龄的岩石. 本次工作在宿松杂岩片麻岩样 品8311中获得1987Ma的加权平均年龄, 很好地证明宿

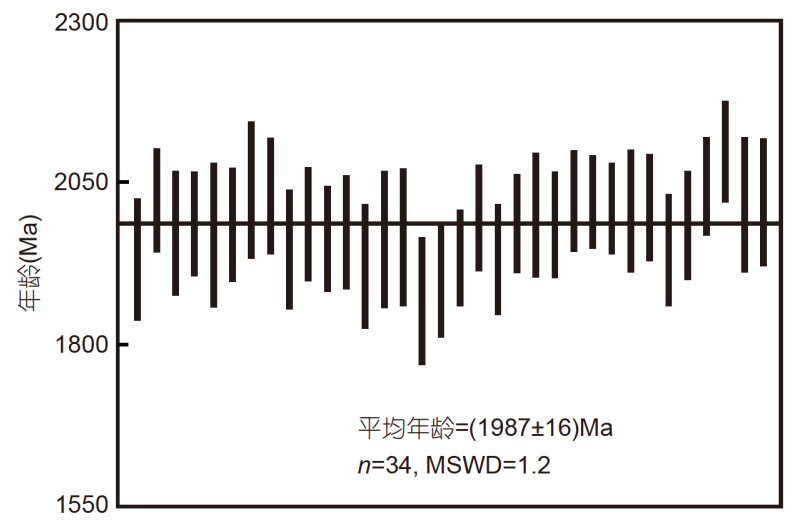

图 6 宿松杂岩带黑云花岗片麻岩谐和图及加权平均年龄 

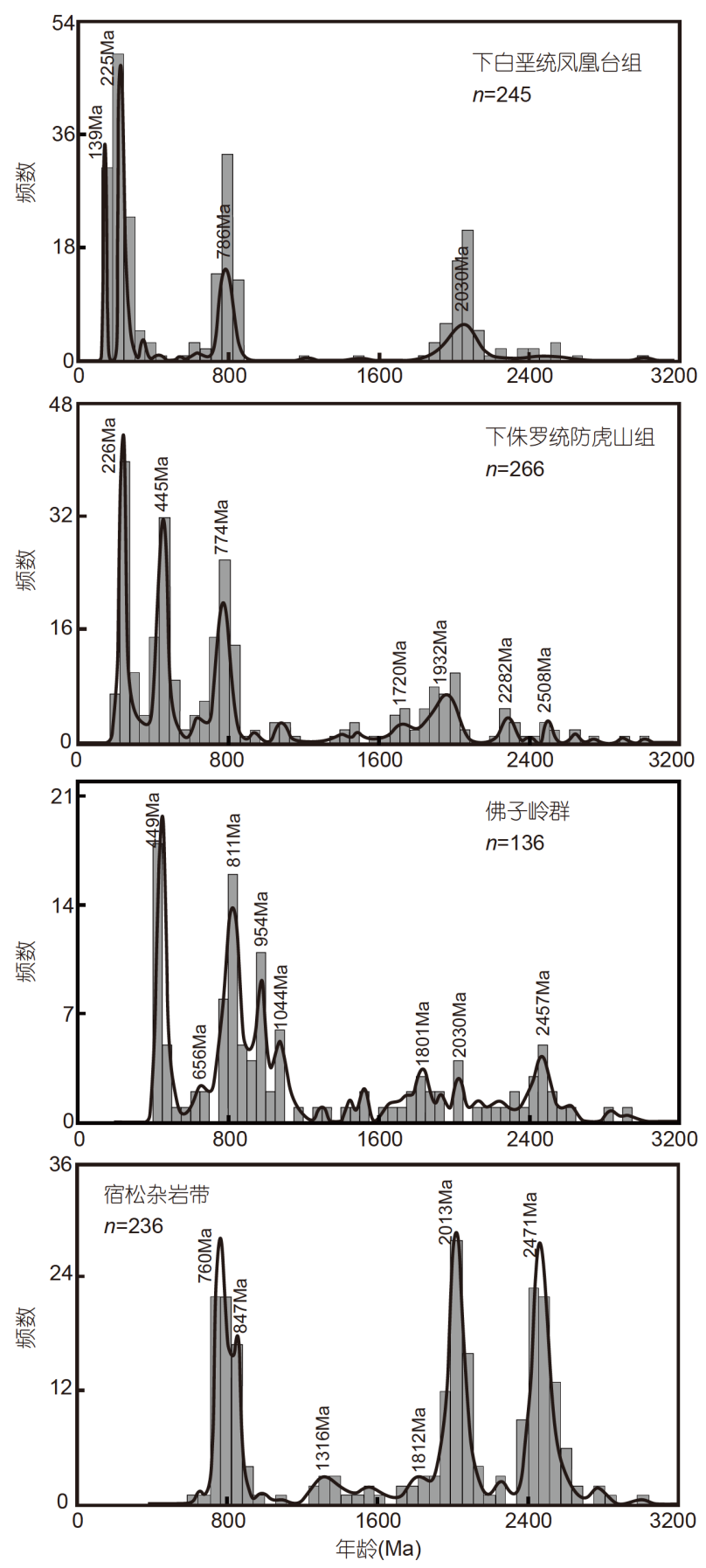

图 7 佛子岭群与宿松杂岩带年龄结果分布频谱图

凤凰台组数据据Wan等(2005)和Zhu等(2017); 防虎山组数据据 $\mathrm{Li}$ 等 (2005)和Zhu等(2017)与本次工作; 佛子岭群数据据石永红等(2014) 和Zhu等(2017); 宿松杂岩数据据石永红等(2012)和李俊辉等(2016) 及本次工作

松杂岩带内的确存在仅含有古元古代年龄信息的岩 石. 虽然佛子岭群也存在相应的锆石, 但其比例明显较
少(图7). 而且, 佛子岭群为古生代复理石沉积(徐树桐 等, 1992; Chen等, 2003; Zheng等, 2005; Zhu等, 2017), 属于多时代物质的混合, 无法形成仅由 $2.0 \sim 1.8 \mathrm{Ga}$ 物质 构成的砾石. 防虎山组中由于含有较多吕梁运动锆石 年龄而被认为部分物源来自于华北板块( $\mathrm{Li}$ 等，2005), 华北板块也的确存在大量 $2.0 \sim 1.8 \mathrm{Ga}$ 年龄信息, 但本次 工作中测量的锆石均具有清晰的震荡环带(图4), Th/U 比明显大于 0.1 (附表 1 ), 表明这些锆石形成于岩浆活动 事件中，明显不同于华北板块该时期年龄主要记录的 变质事件的发生时间(Zhao等，2012; Peng等，2014). 而且, 华北板块2.0 1.8Ga年龄常与 $2.5 \mathrm{Ga}$ 年龄共存, 这 也与防虎山组砾岩中 $2.5 \mathrm{Ga}$ 年龄结果明显较少的特征 不同. 近年来, 越来越多的证据表明华南板块也存在大 量的2.0 1.8Ga年龄信息(Liu等, 2008; Zhou等, 2017). 因而, 防虎山组中砾石应不是来自华北板块, 而应为来 自于华南板块的基底岩石. 结合古水流方向成果(李忠 等, 2000), 可以推测防虎山组旁侧早侏罗世时应主要 出露大别造山带宿松杂岩岩石.

防虎山组砾岩胶结物与长石砂岩中较多的印支 期、古生代物质的加入，表明地表也同时出露有古生 代岩浆岩和高压-超高压变质岩. 需要注意的是, 砾岩 胶结物中仅出现了古生代年龄，而没有任何印支期年 龄信息，直到更上部的长石砂岩中印支期年龄才大量 出现, 这表明古生代岩浆岩应位于宿松杂岩相邻位置, 而高压-超高压变质岩则相对较远. 防虎山组主要表现 为一套河流相碎屑岩, 指示其物质经过了一定距离的 搬运; 但防虎山组砾岩中低成熟度的片麻岩砾石占了 非常大的比例, 又显示其搬运距离并不大. 这两个矛 盾的结论共存于一套地层中的现象表明，防虎山组应 属于多物源的沉积地层. 高压-超高压岩石相对较远, 具有较远距离搬运特征, 这可能也是至今仍没有在防 虎山组中发现榴辉岩砾石的原因; 宿松杂岩则位于防 虎山组旁侧, 形成地层中的砾石.

大别造山带南侧和东侧也发育有与合肥盆地同期 的同造山期沉积盆地，但其下侏罗统地层中均缺失印 支期年龄结果(Yang等, 2000; Grimmer等, 2003). 位于 造山带南侧的黄石盆地中上三叠统-下侏罗统地层以 $2.0 \sim 1.8 \mathrm{Ga}$ 及 $800 \sim 700 \mathrm{Ma}$ 年龄峰为特征, 直到中侏罗统 地层中才开始出现印支期年龄(Yang等, 2000). 造山带 东侧盆地内同样表现为仅在中侏罗统地层中存在极少 量印支期锆石年龄(Grimmer等, 2003). 因而, 大别造山 
带内高压-超高压变质岩在早侏罗世时应主要出露于 造山带北部, 且其出露范围可能相对较小; 其他位置则 仍主要出露宿松杂岩带(图8).

防虎山组长石砂岩样品NF83中存在时代多样的 年龄结果(图5), 其中印支期年龄峰来自于大别造山带 内的高压-超高压变质岩( $\mathrm{Li}$ 等, 2005). 众所周知, 大别 造山带内岩石原岩主要来自于华南板块(Hacker等, 1998；Zheng等，2006)，因而防虎山组中这些 $500 \sim 400 \mathrm{Ma}$ 年龄结果也有可能来自于造山带原岩. 但 防虎山组中 $500 \sim 400 \mathrm{Ma}$ 年龄结果在所有数据中的比例 明显高于造山带内岩石，同时也明显高于北淮阳单元 内的佛子岭群，显然来自于其他物源. 近年来的工作 发现，大别造山带也存在早古生代岛弧岩浆活动(Zhu 等，2017)，因而该年龄更有可能来自于早古生代岛弧 岩浆岩的剥蚀. 同样的, 防虎山组中明显较多的
$2.0 \sim 1.8 \mathrm{Ga}$ 及 $800 \sim 700 \mathrm{Ma}$ 的年龄结果既可以来自于佛 子岭群, 也可以来自宿松杂岩带. 但防虎山组缺失佛子 岭群中明显存在的1000 900Ma年龄结果, 而且砾岩中 2.0 1.8Ga片麻岩、石英岩砾石的存在，表明其物源区 更有可能是宿松杂岩, 而并不包括佛子岭群. 因此, 防 虎山组的物源更有可能是高压-超高压变质岩、古生 代岛弧岩浆岩及宿松杂岩的混合物源.

\section{2 造山带岩石向北折返的讨论}

本次工作中样品9304的年龄结果分布与高压-超 高压岩石基本一致, 显示其物源应主要为高压-超高压 变质岩单元.9306旁侧出露有新元古代岩浆岩变质形 成的卢镇关群，该物源的加入会导致新元古代年龄明 显增加，其他年龄结果所占比例明显减少. 而仅有少 量印支期年龄分布于该样品中的现象表明，样品9306

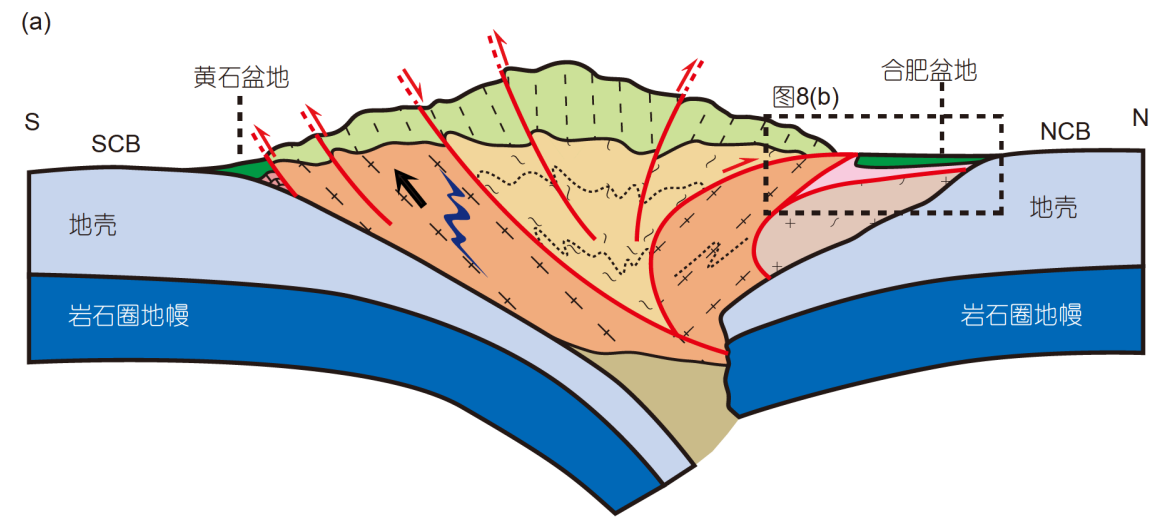

(b)

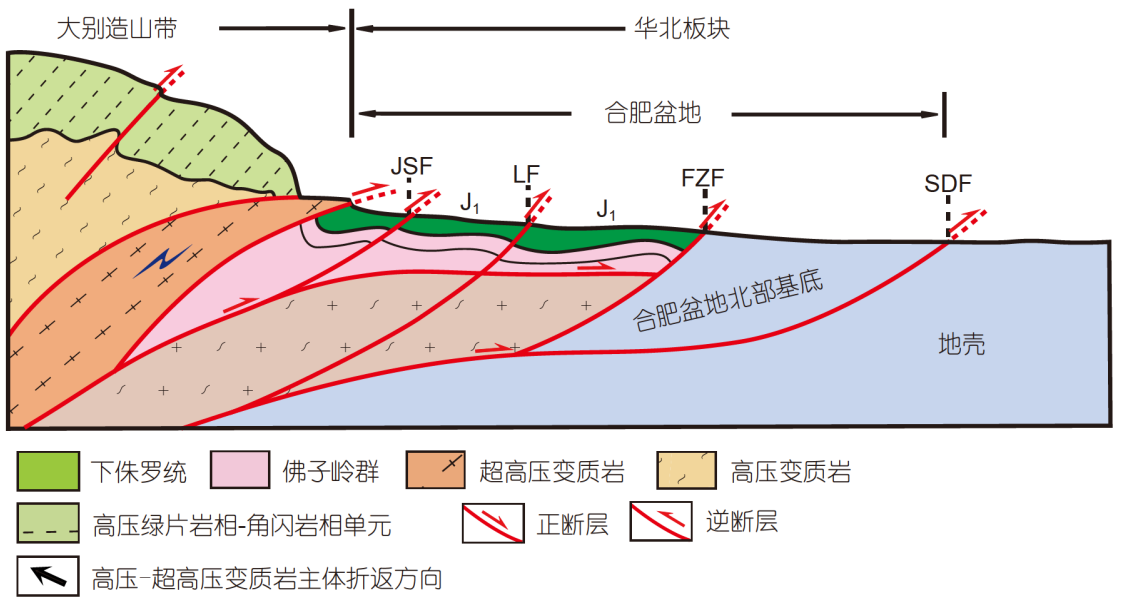

图 8 大别造山带早侏罗世地表岩石单元分布剖面图

SCB, 华南板块; NCB, 华北板块; XMSZ, 晓天-磨子潭剪切带; JSF, 金寨-舒城断裂; LF, 六安断裂; SSF, 蜀山断裂; FZF, 肥中断裂; SDF, 寿县-定 远断裂. 深部资料据赵宗举等(2000) 
的物源主要为卢镇关群, 少量物质来源于高压-超高压 变质岩单元. 但佛子岭群中典型的500 400Ma、 1000 900Ma特征年龄峰均没有出现于三尖铺组砂岩 中，指示佛子岭群在中侏罗世时也没有作为合肥盆地 的物源区存在. 佛子岭群出露于合肥盆地南侧, 分割 了盆地沉积区与造山带内其他构造-岩石单元. 因而, 如果佛子岭群一直出露于地表，则合肥盆地中所有地 层碎屑锆石年龄中都应出现佛子岭群的特征年龄峰. 但实际上除了防虎山组缺失1000 900Ma特征年龄峰 外，不但中侏罗统三尖铺组碎屑锆石年龄与佛子岭群 完全不同，而且下白严统凤凰台组、周公山组也仅存 在与高压-超高压变质岩一致的碎屑锆石年龄(Wan等, 2005; Zhu等, 2017)，表明佛子岭群在整个侏罗纪并未 作为物源区存在. 而导致佛子岭群不作为物源区出现 的最可能的原因就是，造山带内其他岩石掩盖了佛子 岭群.

大量的工作表明，大别造山带内俯冲的岩石除主 体向SE方向折返外，还存在部分岩石向北的逆冲活动 (赵宗举等, 2000; 杨文采, 2003; Liu等, 2003). 在此过程 中，形成了位于华北板块南缘的合肥后陆盆地(Liu等, 2003，2010；Meng等，2007; 朱光等，2011；Zhu等, 2017). 大别造山带中目前出露的佛子岭群表现为强烈 褶皱变形，属于多期构造活动叠加的产物(Faure等, 2003; 林伟等, 2005); 肥西地区防虎山组出露位置, 防 虎山组砾岩直接覆盖于隶属于佛子岭群的石墨片岩之 上(石永红等, 2014), 其他地区也存在中侏罗统三尖铺 组覆盖于北淮阳单元之上的现象( Li等, 2005; Meng等, 2007). 这表明造山作用导致靠近造山带的佛子岭群被 褶皱挠曲，而相对较远部分则被掩盖于合肥盆地之下， 形成盆地基底.

佛子岭群不作为合肥盆地南缘侏罗系地层的物源 区出现, 存在两种可能:一是大别造山带存在向北折返 的岩石单元，二是造山带北缘存在堆积的宿松杂岩岩 石. 大别造山带高压-超高压岩石折返主要发生于 215Ma左右(Li等，2000；Liu等，2006; Wawrzenitz等， 2006; Zheng等, 2006), 并持续至早侏罗世. 合肥盆地最 老地层形成于早侏罗世时，时间上属于折返过程的晚 期阶段. 考虑到防虎山组出露位置与佛子岭群南界相 距较远, 且砾岩中砾石主要由 $2.0 \sim 1.8 \mathrm{Ga}$ 物质构成, 因 而部分宿松杂岩带岩石可能存在向北折返，不但掩盖 了佛子岭群，也为防虎山组砾岩中的砾石提供了物源
(图8). 安参1井也揭示有下侏罗统地层存在(徐佑德等, 2002), 表明合肥盆地下侏罗统的发育范围可能向北延 伸于肥中断裂一带(图8b).

第二种形成机制则与折返的岩石无关. 防虎山组 砾岩中部分石英岩砾石显示未变形状态(图3d), 其中 也没有印支期变质作用的年龄记录，指示相关岩石并 未经历过明显的变质-变形过程. 大别造山带在俯冲过 程中形成了规模较大的构造加积楔(Zheng等，2005), 部分岩石堆积在俯冲通道周边. 在此过程中, 作为华 南板块盖层的宿松杂岩主体向下俯冲，部分与佛子岭 群一起形成构造加积楔, 并堆积于佛子岭群之上，在 合肥盆地形成后作为物源形成防虎山组中的砾石. 但 由于后碰撞伸展过程中强烈的隆升作用将相关岩石剥 蚀殆尽, 该过程还需开展进一步的工作来证明.

\section{6 结语}

（1）合肥盆地下侏罗统防虎山组砾岩及其中砾石 的碎屑锆石年龄结果主要分布于 $2.0 \sim 1.8 \mathrm{Ga}$, 与大别造 山带宿松杂岩内片麻岩一致，表明宿松杂岩为防虎山 组主要物源区之一。

（2）防虎山组出露位置虽然邻近大别造山带北淮 阳单元，但其年龄结果中缺失佛子岭群特征的 $1000 \sim 900 \mathrm{Ma}$ 年龄结果, 且 $500 \sim 400 \mathrm{Ma}$ 年龄结果所占比 例明显高于佛子岭群. 结合砾岩中砾石主要来自于宿 松杂岩的结论, 可以推断防虎山组物源更可能是高压超高压变质岩、古生代岛弧岩浆岩及宿松杂岩形成的 混合物源, 而不包括佛子岭群.

（3）佛子岭群不作为合肥盆地南缘侏罗系地层物 源存在的原因是，其在侏罗纪时被其他造山带岩石掩 盖. 该过程存在两种可能的机制：一是部分造山带岩 石在早侏罗世时存在宿松杂岩向北的折返，导致佛子 岭群南部岩石被掩盖，北部形成合肥后陆盆地基底; 二是造山过程中宿松杂岩岩石堆积在造山带北缘，掩 盖了佛子岭群岩石并形成防虎山组中砾石. 但具体的 细节还需进一步工作来证明.

致谢非常感谢林伟研究员及另一位匿名评审专家审阅 了全文并提出建设性修改意见。锆石定年工作得到了合 肥工业大学质谱实验室李全忠、汪方跃副教授的帮助, 在此表示衰心的感谢. 


\section{参考文献}

江来利, 吴维平, 刘贻灿, 李惠民. 2003. 大别山南部宿松杂岩的U-Pb 锆石年龄和Ar-Ar角闪石年龄及其地质意义. 岩石学报, 19: 497505

李俊辉, 于洋, 韦龙猛, 胡昭平, 陈福坤. 2016. 大别山造山带宿松岩 群锆石 $\mathrm{U}-\mathrm{Pb}$ 年龄和 $\mathrm{Nd}$ 同位素特征: 宿松地体物源和属性. 地球科 学与环境学报, 38: 21-33

李秋立, 杨亚楠, 石永红, 林伟. 2013. 榴辉岩中金红石U-Pb定年: 对 大陆碰撞造山带形成和演化的制约. 科学通报, 58: 2279-2284

李任伟, 孟庆任, 李双应. 2005. 大别山及邻区侏罗和石炭纪时期盆山耦合: 来自沉积记录的认识. 岩石学报, 21: 1133-1143

李曙光, 李秋立, 侯振辉, 杨蔚, 王莹. 2005. 大别山超高压变质岩的 冷却史及折返机制. 岩石学报, 21: 1117-1124

李忠, 孙枢, 李任伟, 江茂生. 2000. 合肥盆地中生代充填序列及其对 大别山造山作用的指示. 中国科学 D辑: 地球科学, 30: 256-263

林伟, 王清晨, Faure M, Arnaud N. 2005. 从北淮阳构造带的多期变形 透视大别山构造演化. 中国科学 $\mathrm{D}$ 辑: 地球科学, 35: 127-139

刘国生, 朱光, 牛漫兰, 宋传中, 王道轩. 2006. 合肥盆地东部中-新生 代的演化及其对郯庐断裂带活动的响应. 地质科学, 41: 256-269

刘景波, 张灵敏, 叶凯, 苏文, 程南飞. 2013. 大别山北部卢镇关群变 质火山岩和共生变质的花岗岩全岩和锆石氧同位素、锆石U-Pb 年代学研究. 岩石学报, 29: 1511-1524

孟庆任, 李任伟, 李双应. 2005. 中生代合肥盆地南部的沉积过程与 大别山变质地体的剥露. 岩石学报, 21: 1145-1156

石永红, 曹晟, 王娟, 聂峰, 康涛. 2014. 北淮阳变质单元岩石学、年 代学分析及对大别造山带构造缝合线位置的探究. 地质科学, 49: 378-393

石永红, 王次松, 康涛, 徐旭峰, 林伟. 2012. 安徽省宿松变质杂岩岩 石学特征和锆石U-Pb年龄研究. 岩石学报, 28: 3389-3402

王清晨, 林伟. 2002. 大别山碰撞造山带的地球动力学. 地学前缘, 9: $257-265$

王勇生，白桥，杨秉飞. 2018. 北大别单元混合岩的变形及锆石年代 学特征：对混合岩变形时间的限定. 中国科学：地球科学，48: 980-996

王勇生, 王海峰, 盛勇, 向必伟. 2014. 大别造山带早白严世抬升演化 研究一一来自岩体侵位深度的证据. 中国科学: 地球科学, 44: 200-212

魏春景, 陈斌, 张翠光, 陈晶. 2000 . 大别地区的变质作用及与碰撞造 山过程的关系. 地质力学学报, 6: 25-38

吴元保, 郑永飞, 龚冰, 唐俊, 赵子福, 查向平. 2004. 北淮阳庐镇关岩 浆岩锆石U-Pb年龄和氧同位素组成. 岩石学报, 20: 1007-1024

吴元保, 郑永飞. 2004. 锆石成因矿物学研究及其对U-Pd年龄解释的 制约. 科学通报, 49: 1589-1604

徐树桐, 江来利, 刘贻灿, 张勇. 1992. 大别山区(安徽部分)的构造格 局和演化过程. 地质学报, 66: 1-14
徐佑德, 赵明, 徐春华, 徐明, 邱连贵. 2002. 合肥盆地安参1井中生代 地层特征. 石油实验地质, 24: 223-227

杨坤光, 程万强, 朱清波, 李学刚. 2011. 论大别山南缘襄樊-广济断裂 的两次向南逆冲推覆. 地质论评, 57: 480-494

杨坤光, 马昌前, 许长海, 杨巍然. 1999. 北淮阳构造带与大别造山带 的差异性隆升. 中国科学 D辑: 地球科学, 29: 97-103

杨文采. 2003. 东大别超高压变质带的深部结构. 中国科学 D辑: 地球 科学, 33: 183-192

张国伟, 孟庆任, 于在平, 孙勇, 周鼎武, 郭安林. 1996. 秦岭造山带的 造山过程及其动力学特征. 中国科学 $\mathrm{D}$ 辑: 地球科学, 26: 193-200

赵田, 朱光, 林少泽, 宋利宏. 2014. 缸庐断裂带南段张八岭群变质岩 的原岩时代及其构造意义. 地质论评, 60: 1265-1283

赵子福, 郑永飞. 2009. 俯冲大陆岩石圈重熔: 大别-苏鲁造山带中生 代岩浆岩成因. 中国科学 D辑: 地球科学, 39: 888-909

赵宗举, 杨树锋, 周进高, 竺国强, 陈汉林. 2000. 合肥盆地逆掩冲断 带地质-地球物理综合解释及其大地构造属性. 成都理工学院学 报, 27: 151-157

朱光, 刘程, 顾承串, 张帅, 李云剑, 苏楠, 肖世梆. 2018. 㸚庐断裂带 晚中生代演化对西太平洋俯冲历史的指示. 中国科学: 地球科学, 48: $415-435$

朱光, 朴学峰, 张力, 张必龙, 陈印, 胡召齐. 2011. 合肥盆地伸展方向 的演变及其动力学机制. 地质论评, 57: 153-165

Andersen T. 2005. Detrital zircons as tracers of sedimentary provenance: Limiting conditions from statistics and numerical simulation. Chem Geol, 216: 249-270

Belousova E, Griffin W, O’Reilly S Y, Fisher N. 2002. Igneous zircon: Trace element composition as an indicator of source rock type. Contrib Mineral Petrol, 143: 602-622

Chen F K, Guo J H, Jiang L L, Siebel W, Cong B L, Satir M. 2003. Provenance of the Beihuaiyang lower-grade metamorphic zone of the Dabie ultrahigh-pressure collisional orogen, China: Evidence from zircon ages. J Asian Earth Sci, 22: 343-352

Chen R X, Ding B H, Zheng Y F, Hu Z C. 2015. Multiple episodes of anatexis in a collisional orogen: Zircon evidence from migmatite in the Dabie orogen. Lithos, 212-215: 247-265

Faure M, Lin W, Schärer U, Shu L, Sun Y, Arnaud N. 2003. Continental subduction and exhumation of UHP rocks. Structural and geochronological insights from the Dabieshan (East China). Lithos, 70: 213-241

Grimmer J C, Ratschbacher L, McWilliams M, Franz L, Gaitzsch I, Tichomirowa M, Hacker B R, Zhang Y. 2003. When did the ultrahigh-pressure rocks reach the surface? $\mathrm{A}{ }^{207} \mathrm{~Pb} /{ }^{206} \mathrm{~Pb}$ zircon, ${ }^{40} \mathrm{Ar} /{ }^{39} \mathrm{Ar}$ white mica, Si-in-white mica, single-grain provenance study of Dabie Shan synorogenic foreland sediments. Chem Geol, 197: $87-110$

Hacker B R, Ratschbacher L, Webb L, McWilliams M O, Ireland T, 
Calvert A, Dong S, Wenk H R, Chateigner D. 2000. Exhumation of ultrahigh-pressure continental crust in east central China: Late Triassic-Early Jurassic tectonic unroofing. J Geophys Res, 105: 13339-13364

Hacker B R, Ratschbacher L, Webb L, Ireland T, Walker D, Shuwen D. 1998. U/Pb zircon ages constrain the architecture of the ultrahighpressure Qinling-Dabie Orogen, China. Earth Planet Sci Lett, 161: $215-230$

Hacker B R, Wang Q C. 1995. Ar/Ar geochronology of ultrahighpressure metamorphism in central China. Tectonics, 14: 994-1006

He Y S, Li S G, Hoefs J, Huang F, Liu S A, Hou Z H. 2011. Postcollisional granitoids from the Dabie orogen: New evidence for partial melting of a thickened continental crust. Geochim Cosmochim Acta, 75: 3815-3838

Ji W B, Lin W, Faure M, Shi Y H, Wang Q C. 2017. The early Cretaceous orogen-scale Dabieshan metamorphic core complex: Implications for extensional collapse of the Triassic HP-UHP orogenic belt in east-central China. Int J Earth Sci-Geol Rundsch, 106: $1311-1340$

Li S G, Jagoutz E, Chen Y Z, Li Q L. 2000. Sm-Nd and Rb-Sr isotopic chronology and cooling history of ultrahigh pressure metamorphic rocks and their country rocks at Shuanghe in the Dabie Mountains, Central China. Geochim Cosmochim Acta, 64: 1077-1093

Li R W, Wan Y S, Cheng Z Y, Zhou J X, Li S Y, Jin F Q, Meng Q R, Li Z, Jiang M S. 2005. Provenance of Jurassic sediments in the Hefei Basin, east-central China and the contribution of high-pressure and ultrahigh-pressure metamorphic rocks from the Dabie Shan. Earth Planet Sci Lett, 231: 279-294

Lin W, Enami M, Faure M, Schärer U, Arnaud N. 2007. Survival of eclogite xenolith in a Cretaceous granite intruding the Central Dabieshan migmatite gneiss dome (Eastern China) and its tectonic implications. Int J Earth Sci-Geol Rundsch, 96: 707-724

Lin W, Ji W B, Faure M, Wu L, Li Q L, Shi Y H, Schärer U, Wang F, Wang Q C. 2015. Early Cretaceous extensional reworking of the Triassic HP-UHP metamorphic orogen in Eastern China. Tectonophysics, 662: 256-270

Lin W, Shi Y H, Wang Q C. 2009. Exhumation tectonics of the HPUHP orogenic belt in Eastern China: New structural-petrological insights from the Tongcheng massif, Eastern Dabieshan. Lithos, 109: $285-303$

Liu F L, Gerdes A, Liou J G, Xue H M, Liang F H. 2006. SHRIMP U$\mathrm{Pb}$ zircon dating from Sulu-Dabie dolomitic marble, eastern China: Constraints on prograde, ultrahigh-pressure and retrograde metamorphic ages. J Metamorph Geol, 24: 569-589

Liu X M, Gao S, Diwu C R, Ling W L. 2008. Precambrian crustal growth of Yangtze Craton as revealed by detrital zircon studies. Am
J Sci, 308: 421-468

Liu Y C, Li S G, Xu S T, Jahn B M, Zheng Y F, Zhang Z Q, Jiang L L, Chen G B, Wu W P. 2005. Geochemistry and geochronology of eclogites from the northern Dabie Mountains, central China. J Asian Earth Sci, 25: 431-443

Liu S F, Heller P L, Zhang G W. 2003. Mesozoic basin development and tectonic evolution of the Dabieshan orogenic belt, central China. Tectonics, 22: 1038

Liu S F, Steel R, Zhang G W. 2005. Mesozoic sedimentary basin development and tectonic implication, northern Yangtze Block, eastern China: Record of continent-continent collision. J Asian Earth Sci, 25: 9-27

Liu S F, Zhang G W, Ritts B D, Zhang H P, Gao M X, Qian C C. 2010. Tracing exhumation of the Dabie Shan ultrahigh-pressure metamorphic complex using the sedimentary record in the Hefei Basin, China. Geol Soc Am Bull, 122: 198-218

Ludwig K R. 2004. User's Manual for Isoplot 3.14: A Geochronological Toolkit for Microsoft Excel. California: Berkeley Geochronology Center

Mattauer M, Matte P, Malavieille J, Tapponnier P, Maluski H, Qin X Z Q, Lun L Y, Qin T Y. 1985. Tectonics of the Qinling belt: Build-up and evolution of eastern Asia. Nature, 317: 496-500

Meng Q R, Li S Y, Li R W. 2007. Mesozoic evolution of the Hefei Basin in eastern China: Sedimentary response to deformations in the adjacent Dabieshan and along the Tanlu fault. Geol Soc Am Bull, 119: 897-916

Okay A I, Şengör C A M. 1992. Evidence for intracontinental thrustrelated exhumation of the ultra-high-pressure rocks in China. Geology, 20: 411-414

Peng P, Wang X P, Windley B F, Guo J H, Zhai M G, Li Y. 2014. Spatial distribution of $\sim 1950-1800$ Ma metamorphic events in the North China Craton: Implications for tectonic subdivision of the craton. Lithos, 202-203: 250-266

Ratschbacher L, Hacker B R, Webb L E, McWilliams M, Ireland T, Dong S, Calvert A, Chateigner D, Wenk H R. 2000. Exhumation of the ultrahigh-pressure continental crust in east central China: Cretaceous and Cenozoic unroofing and the Tan-Lu fault. J Geophys Res, 105: 13303-13338

Wan Y S, Li R W, Wilde S A, Liu D Y, Chen Z Y, Yan L, Song T R, Yin X Y. 2005. UHP metamorphism and exhumation of the Dabie Orogen, China: Evidence from SHRIMP dating of zircon and monazite from a UHP granitic gneiss cobble from the Hefei Basin. Geochim Cosmochim Acta, 69: 4333-4348

Wang E, Meng Q R, Burchfield B C, Zhang G W. 2003. Mesozoic large-scale lateral extrusion, rotation, and uplift of the TongbaiDabie Shan belt in east China. Geology, 31: 307-310 
Wang Q, Wyman D A, Xu J F, Jian P, Zhao Z H, Li C F, Xu W, Ma J L, He B. 2007. Early Cretaceous adakitic granites in the Northern Dabie Complex, central China: Implications for partial melting and delamination of thickened lower crust. Geochim Cosmochim Acta, 71: 2609-2636

Wang X D, Neubauer F, Genser J, Yang W R. 1998. The Dabie UHP unit, Central China: A Cretaceous extensional allochthon superposed on a Triassic orogen. Terra Nova, 10: 260-267

Wang Y S, Xiang B W, Zhu G, Jiang D Z. 2011. Structural and geochronological evidence for Early Cretaceous orogen-parallel extension of the ductile lithosphere in the northern Dabie orogenic belt, East China. J Struct Geol, 33: 362-380

Wawrzenitz N, Romer R L, Oberhänsli R, Dong S. 2006. Dating of subduction and differential exhumation of UHP rocks from the Central Dabie Complex (E-China): Constraints from microfabrics, $\mathrm{Rb}-\mathrm{Sr}$ and U-Pb isotope systems. Lithos, 89: 174-201

Wu Y B, Zheng Y F, Zhang S B, Zhao Z F, Wu F Y, Liu X M. 2007 Zircon $\mathrm{U}-\mathrm{Pb}$ ages and $\mathrm{Hf}$ isotope compositions of migmatite from the North Dabie terrane in China: Constraints on partial melting. J Metamorph Geol, 25: 991-1009

Yan J, Liu J M, Li Q Z, Xing G F, Liu X Q, Xie J C, Chu X Q, Chen Z H. 2015. In situ zircon Hf-O isotopic analyses of late Mesozoic magmatic rocks in the Lower Yangtze River Belt, central eastern China: Implications for petrogenesis and geodynamic evolution. Lithos, 227: 57-76

Yang J H, Cawood P A, Du Y S. 2010. Detrital record of mountain building: Provenance of Jurassic foreland basin to the Dabie Mountains. Tectonics, 29: TC4011

Yin A, Nie S. 1993. An indentation model for the North and South China collision and the development of the Tan-Lu and Honam Fault Systems, eastern Asia. Tectonics, 12: 801-813

Zhai M G, Cong B L, Zhao Z, Wang Q C, Wang G, Jiang L L. 1995. Petrological-tectonic units in the coesite-bearing metamorphic terrain of the Dabie Mountains, central China and their geotectonic implication. J Asian Earth Sci, 11: 1-13

Zhao G C, Cawood P A, Li S Z, Wilde S A, Sun M, Zhang J, He Y H, Yin C Q. 2012. Amalgamation of the North China Craton: Key issues and discussion. Precambrian Res, 222-223: 55-76

Zheng Y F, Fu B, Gong B, Li L. 2003. Stable isotope geochemistry of ultrahigh pressure metamorphic rocks from the Dabie-Sulu orogen in China: Implications for geodynamics and fluid regime. Earth-Sci Rev, 62: 105-161

Zheng Y F, Zhao Z F, Wu Y B, Zhang S B, Liu X, Wu F Y. 2006. Zircon $\mathrm{U}-\mathrm{Pb}$ age, $\mathrm{Hf}$ and $\mathrm{O}$ isotope constraints on protolith origin of ultrahigh-pressure eclogite and gneiss in the Dabie orogen. Chem Geol, 231: 135-158

Zheng Y F, Zhou J B, Wu Y B, Xie Z. 2005. Low-grade metamorphic rocks in the Dabie-Sulu orogenic belt: A passive-margin accretionary wedge deformed during continent subduction. Int Geol Rev, 47: 851-871

Zheng Y F, Wu Y B, Chen F K, Gong B, Li L, Zhao Z F. 2004. Zircon $\mathrm{U}-\mathrm{Pb}$ and oxygen isotope evidence for a large-scale ${ }^{18} \mathrm{O}$ depletion event in igneous rocks during the Neoproterozoic. Geochim Cosmochim Acta, 68: 4145-4165

Zhou G Y, Wu Y B, Wang H, Qin Z W, Zhang W X, Zheng J P, Yang S H. 2017. Petrogenesis of the Huashanguan A-type granite complex and its implications for the early evolution of the Yangtze Block. Precambrian Res, 292: 57-74

Zhu G, Wang Y S, Liu G S, Niu M L, Xie C L, Li C C. $2005 .{ }^{40} \mathrm{Ar} /{ }^{39} \mathrm{Ar}$ dating of strike-slip motion on the Tan-Lu fault zone, East China. J Struct Geol, 27: 1379-1398

Zhu G, Wang Y S, Wang W, Zhang S, Liu C, Gu C C, Li Y J. 2017. An accreted micro-continent in the north of the Dabie Orogen, East China: Evidence from detrital zircon dating. Tectonophysics, 698: $47-64$ 